\title{
AFAMADA ESTÓRIA: "FAMIGERADO" (PRIMEIRAS ESTÓRIAS) E O CANTO IX DA ODISSEIA *
}

\author{
Christian Werner $\star \star$ \\ Universidade de São Paulo
}

\begin{abstract}
This paper presents as interpretation of the short-story "Famigerado" by João Guimarães Rosa (Primeiras estórias) and the Polyphemus' episode in Homer's Odyssey based on many common elements: the smart use of language; an adjective related to fame that occupies a central place in the story ("famigerado"; "polyphêmos"); a hospitality scene structuring the story; and the dialectic movement between violence and cunning.
\end{abstract}

KEYWORDS: "Famigerado"; Primeiras Estórias; Polyphemos; Odysseus; Odyssey.

na Luiza Martins Costa, ${ }^{1}$ em trabalho pioneiro, demonstrou não só que João Guimarães Rosa (= JGR) conhecia Homero muito bem, mas que vários elementos temáticos e estilísticos da Odisseia e, sobretudo, da Ilíada, podem ser rastreados em textos fundamentais do autor, em especial, em Grande sertão: veredas (= GSV) e "A hora e a vez de Augusto Matraga". Parte do trabalho de Martins Costa foi de crítica genética, o exame detalhado dos chamados "Cadernos Homero", um reflexo da leitura cuidadosa do poeta grego pelo romancista mineiro no

\footnotetext{
* Uma primeira versão de parte deste texto foi apresentada em Diamantina em abril de 2012 por ocasião do "V Simpósio Lendo, vendo e ouvindo o passado"; agradeço pela oportunidade aos organizadores do evento, bem como a Marcus Mazzari pela leitura da presente versão.

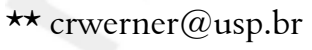

${ }^{1}$ Cf. Martins Costa, A. L. Rosa ledor de Homero. Revista da USP. São Paulo, n. 36, p. 46-73, 1997/1998.
} 
entorno da época em que trabalhou na terceira edição de Sagarana e em GSV. Para os meus propósitos, é suficiente a demonstração de que Homero foi uma leitura importante, quiçá fundamental, para JGR, pois não pretendo provar a influência consciente do episódio odisseico da vitória de Odisseu sobre o ciclope Polifemo no canto IX do poema sobre o conto "Famigerado" de Primeiras estórias $(=\mathrm{PE}),{ }^{2}$ mas tão somente defender que a leitura de ambos os textos, em paralelo, pode ser profícua para a interpretação de ambos, um metódo bastante comum em estudos de recepção. Isso posto, admito de antemão que minha investigação me convenceu de que o episódio de Polifemo é uma importante matriz para o conto em questão; na verdade, não conheço outra história que tenha tantos e tão precisos paralelos com a história do jagunço Damázio.

O tipo de análise aqui proposto, ao se pautar pelo que o próprio JGR definiu como boa literatura na entrevista com Günter Lorenz, ${ }^{3}$ vai na contramão de uma análise como, por exemplo, a de Ana Paula Pacheco, ${ }^{4}$ que buscou mostrar que, muito mais que criar uma realidade outra, a criação rosiana depende de - ou gera - uma escamoteação das contradições da realidade brasileira que estão na base dessa criação, ou seja, as diferenças sociais, econômicas e culturais entre o sertão e o autor e, consequentemente, seus narradores. Para a autora, não há mimese da realidade brasileira, mas somente a visão parcial de um representante da elite sobre essa realidade. Através do excesso daquilo que não é "brasileiro", seja na linguagem, seja nos jogos intertextuais, gera-se a ausência, a falta da tematização das contradições inerentes aos processos históricos que constituem a sociedade brasileira. ${ }^{5} \mathrm{O}$ que vou procurar mostrar é que, na base da leitura de Ana Pacheco e outros, procede-se a uma escamoteação do conflito nuclear da própria obra, ou melhor, a visão de mundo que acabei de esquematizar é como que inoculada na obra para "provar" que esse conflito nuclear é aparente e secundário em relação aos conflitos

\footnotetext{
${ }^{2}$ Abaixo, os trechos da Odisseia (= Od.) são de minha tradução do poema ainda inédita, para a qual o texto base foi Homeri Odyssea. Recognovit Helmut van Thiel. Hildesheim: Olms, 1991. As citações de "Famigerado" e de outros contos do volume, que abaixo serão acompanhadas pelo número da página, são de Rosa, J. G. Primeiras estórias. $3^{\text {a }}$ edição. Rio de Janeiro: José Olympio, 1967.

${ }^{3}$ Cf. Lorenz, G. Diálogo com Guimarães Rosa. In: Coutinho, E. F. (Org.) Guimarães Rosa. Rio de Janeiro: Civilização Brasileira, 1983, p. 61-97.

${ }^{4}$ Pacheco, A. P. Astúcia de classe: "Famigerado", de Guimarães Rosa, e o lugar do escritor. Terceira margem. Rio de Janeiro, vol. XXI, p. 131-139, 2009.

${ }^{5}$ Cf. Pacheco, op. cit., p. 130-131.
} 
"reais", ou seja, aqueles que pressupõem a interação entre o autor e sua matéria, o processo histórico brasileiro. Nessa abordagem, o bom crítico é aquele que revela a infraestrutura, a essência por trás da mera aparência da superestrutura. Mais que isso: o bom crítico é aquele que não perpetua o próprio ato inicial do autor, qual seja, driblar a diferença; o mau crítico é aquele que goza com jogos literários dissociados de referentes e processos históricos.

Bastante distinta dessa chave interpretativa é a leitura de Kathrin Rosenfield, que busca identificar nos contos seu "lirismo atemporal". Para Rosenfield, porém, um tema em especial, também presente em GSV, é aprofundado ao longo de PE, o da "recuperação da totalidade ou da intensidade perdidas por intermédio do merecimento, da ascese física e espiritual". 7 Com isso, contos como "Famigerado" são deslocados para um curioso espaço a priori de "menor nobreza estética".

Antes de iniciar minha proposta de interpretação, faço um breve resumo das duas histórias. Na Odisseia, trata-se da primeira grande aventura narrada por Odisseu ao povo feácio, durante um banquete, logo após revelar sua identidade. Estamos no canto IX do poema, e o herói, quase dez anos após o fim da guerra de Troia, ainda não conseguiu chegar a casa. Após um naufrágio, chega a uma ilha que parece abrigar um povo afável e disposto a levá-lo a Ítaca, sua terra. No final de um longo dia de convivência com o povo feácio, o próprio Odisseu narra o que lhe aconteceu entre o fim da guerra de Troia, na qual os gregos foram vitoriosos graças a ele, que comandou uma elite que penetrou em Troia tocaiada no cavalo de pau, e as aventuras que antecederam o naufrágio mencionado.

No canto IX, Odisseu conta que, após enfrentar os cícones, antigos aliados de Troia, e passar rápido pela terra dos lotófagos, encontra-se na Ilha das Cabras, perdido na sua tentativa de retornar a Ítaca, e decide investigar a ilha vizinha com alguns companheiros. Nesta descobrem a caverna de um ser monstruoso, de força sobre-humana e um olho só, que os prende e decide devorá-los a prestações. A fuga da caverna parece ser impossível, pois dia e noite rocha descomunal impede a saída dos prisioneiros; mesmo se matassem o ciclope, não conseguiriam mover a pedra e morreriam de inanição. Para escaparem da morte iminente,

\footnotetext{
${ }^{6}$ Cf. Rosenfield, K. Desenveredando Rosa. A obra de J. G. Rosa e outros ensaios. Rio de Janeiro: Topbooks, 2006, p. 153.

${ }^{7}$ Cf. Rosenfield, op. cit., p. 156.

${ }^{8}$ Cf. Rosenfield, op. cit., p. 159.
} 
só resta a Odisseu a astúcia. De fato, ele e os companheiros sobreviventes embebedam e cegam o ciclope de nome Polifemo, que, por sua vez, acreditou em seu hóspede-prisioneiro quando este, ao ser indagado acerca de sua identidade, se apresentou como Ninguém (Outis, v. 366), uma palavra que, em grego, é contextualmente polissêmica.

De um lado, "Ninguém" serve como resposta salvadora quando os demais ciclopes, atendendo aos gritos do atacado, chegam à caverna, ainda fechada por enorme pedra, e vão embora após Polifemo responder a uma pergunta deles (v. 403-406): "O que, Polifemo, tanto te perturba para assim gritares/ através da noite imortal e tirar-nos do sono?/ Por certo ninguém (mê tis) teus rebanhos quer contra tua vontade! Por certo ninguém (mê tis) tenta matar-te com ardil ou violência!” A essa indagação Polifemo responde com "Amigos, Ninguém tenta com ardil e não com violência" (v. 408), formulação que, em grego, soa como "Amigos, ninguém tenta, nem com ardil, nem com violência”. Além disso, a forma do pronome "ninguém", em grego, pode ser, dependendo do modo verbal utilizado em uma frase, homônima do substantivo "astúcia" (mêtis), com o que a expressão para "ninguém" usada nos versos 404-405 remete aos truques usados por Odisseu para cegar o ciclope. Além disso, a astúcia continua na manhã seguinte ao cegamento, quando o herói esconde a si próprio e os companheiros restantes debaixo do rebanho ovino do ogro, escapando da caverna: ao liberar seus animais para pastar, Polifemo posta-se na saída e apalpa todos os que passam.

A ligação entre "ninguém" e "astúcia" é clara para os ouvintes/ leitores do poema, de sorte que, ao perceberem o jogo linguístico, como que se tornam cúmplices do herói no engodo aplicado no ciclope e seus vizinhos. Por outro lado, "ninguém", do ponto de vista do ciclope, é o significante natural para se apor ao homúnculo que tem diante de si, que, como diz, é um fracote, um nada. Palavra e coisa se correspondem, assim como o termo "ciclope", que pode ser interpretado como "aquele que tem um (só) olho redondo". Nenhuma razão, portanto, para Polifemo duvidar da veracidade do, para nós, ridículo nome que ouve: sob a ótica do poder bruto do ciclope, os humanos não são nada. Assim, a armadilha de Odisseu é perfeita para a escapada, mas ele, por outro lado - e essa é a reviravolta da história, bem como de toda a longa jornada de retorno de Odisseu -, não consegue deixar o ciclope sem, por fim, revelar sua identidade heroica. Já em seu barco que se afastava da ilha, grita seu nome verdadeiro, o que possibilita a Polifemo fazer uma prece ao pai, o deus Poseidon, pedindo um retorno maximamente difícil do herói para sua pátria. 
No conto de JGR, o jagunço fora da ativa Damázio, ${ }^{9}$ acompanhado de três medrosos seguidores, chega de repente à casa do médico que narra a história, ${ }^{10}$ um duplo do próprio autor, o que é acentuado pela capacidade do narrador resolver o problema em que resulta essa visita graças, em parte, ao seu conhecimento do idioma pátrio. A fama do jagunço o precede e, após desenvolver um longuíssimo preâmbulo durante o qual o médico, atemorizado e cheio de dúvidas, presta atenção a cada detalhe dos gestos e falas do interlocutor, diz a que veio: quer uma fonte confiável para lhe revelar o sentido de uma palavra, "famigerado", que, na Serra do São Âo, um "môço do Govêrno" (p. 11) usara para descrevê-lo e que o ex-jagunço acredita poder ser um xingamento à sua família, em especial, à sua mãe. ${ }^{11}$ O médico explica o termo apenas através daquele que, nos dicionários, é seu sentido primeiro, mas, como sabe o leitor de JGR que conhece a história da palavra ou vai ao dicionário para descobri-la, não está em uso: em uma primeira cadeia de sinônimos, o narrador dá os sinônimos "célebre', 'notório', 'notável"'; logo depois, com palavras mais simples, "importante', que merece louvor, respeito" (p. 12). Com isso, o médico tranquiliza o jagunço, mas, na sequência imediata, surpreende a nós, ao jurar que está dizendo a verdade sobre o sentido do termo com a seguinte formulação: "Olhe: eu, como o sr. me vê, com vantagens, hum, o que eu queria uma hora destas era ser famigerado - bem famigerado, o mais que pudesse!..." (p. 12). O conto termina logo depois, com a despedida de Damázio e um comentário do narrador que discutirei abaixo.

Antes de iniciar a justaposição das duas narrativas, assinale-se que, no tipo de investigação que proponho, o que se busca é a discussão de duas obras, não a demonstração do uso consciente de um autor de algum texto que o precedeu. Vejamos, por exemplo, o que se pode fazer como nome Damázio, o jagunço de "Famigerado", a partir da dicção homérica. O radical do nome Damázio é o mesmo do jagunço maligno do conto "Os irmãos Dagobé" (PE), Damastor, "o mais velho dos quatro irmãos, absolutamente facínoras” (p. 26). Esse radical é o mesmo de um verbo

${ }^{9}$ Cf. Rosa, op. cit., 1967, p. 10: Constando também, se verdade, que de para uns anos êle se serenara-evitava o de evitar. Fie-se, porém, quem, em tais tréguas de pantera?

${ }^{10} \mathrm{O}$ narrador nos informa que, após perguntar ao estranho o que ele queria, respondeume que não estava doente, nem vindo à receita ou consulta (cf. Rosa, op. cit., 1967, p. 10); tratase, portanto, de um médico.

${ }^{11}$ Cf. Wisnik, J. M. O famigerado. Scripta. Belo Horizonte, vol. V, n. 10, p. 177-189, 2002, aqui, p. 181, e Rosenbaum, Y. A palavra como enigma. Aletria. Belo Horizonte, vol. VI, n. 13, p. 84-93, 2006, aqui, p. 90. 
grego que, traduzido por "subjugar", refere-se ao poder assassino dos heróis no campo de batalha (Od. I, 100); na voz passiva, à morte, à derrota dos heróis (Od. I, 237 e III, 90), nesse caso, uma ação cujo agente pode ser representado como a própria morte (Od.III, 410). No canto IX da Odisseia, o verbo é usado três vezes, uma em referência à vitória dos cícones no campo de batalha, "subjugando" Odisseu e seus companheiros, e, duas vezes, em um lamento de Polifemo, que culpa sua derrota por ter sido subjugado pelo vinho que o estranho the oferecera (v. 59, 454 e 516). Ora, como veremos, não há nada que ocupe a função de um narcótico em "Famigerado", mas o nome acentua a afinidade entre os dois contos mencionados, sendo que, em "Os irmãos Dagobé", ele parece ser bastante significativo, pois o mote do conto é justamente a morte do jagunço e a reviravolta, ou seja, o momento em que fica claro que os irmãos, uma vez livres do jugo do irmão defunto, procurarão uma vida bem diferente: que os irmãos faziam aquilo que queria o mais velho é acentuado pela presença do sufixo de agente, grego, no nome, -tor. Mesmo para o leitor que desconsiderar a dialética do subjugar e ser subjugado presente nesses contos, a relação entre a antiga ordem da jagunçagem representada por Damastor e Damázio e a nova ordem do "môço do Govêrno" e da cidade adquire novos ângulos se os dois contos forem lidos em conjunto.

Ataquemos, enfim, o ponto em questão: por que comparar "Famigerado" ao canto IX da Odisseia e não, para ficar no universo grego antigo, à história de Édipo confrontado pela Esfinge, por exemplo? ${ }^{12}$ Trata-se, em ambos os casos, de um embate entre dois adversários de capacidades distintas, sendo que um deles tem nítido poder de vida ou morte sobre o outro. O adversário fisicamente mais fraco, por sua vez, ao contrário de Davi contra Golias, não usa um meio físico para derrotar seu oponente, mas os múltiplos sentidos de uma palavra ou enunciado. O elemento fundamental que aponta para a Odisseia, porém, é que o próprio sentido primeiro de "famigerado" remete ao sentido de "Polifemo", um adjetivo que, pela raridade de seu uso em textos posteriores à Odisseia, talvez tenha ficado associado ao poema: "de muita fama", "de muitas histórias", "de muitas falas". ${ }^{3}$

${ }^{12}$ Cf. abordagem de Rosenbaum op. cit., para quem o conto pode ser lido como uma adivinha às avessas.

${ }^{13}$ Para uma análise de polyphêmos, cf. Werner, C. Reputação e presságio na assembleia homérica: "poluphemos" em "Odisseia” 2, 150. PhaoS. Campinas, vol. IX, p. 29-52, 2009. 
Não é impossível que o adjetivo tenha chamado a atenção de JGR quando leu o poema, pois, embora seja usado só duas vezes, em uma delas qualifica o bardo Fêmio quando ele, em um momento de terror, pede a Odisseu, logo após ter morto os pretendentes de Penélope, que o poupe (Od. XXII, 376). Não fica claro se ele é poupado por dominar uma técnica útil a Odisseu ou porque matá-lo seria um ato ímpio (Od. XXII, 344-353); também não fica claro se Odisseu, ao chamar o aedo de polyphêmos, está elogiando ou debochando do poeta. De qualquer forma, se uma cena (Fêmio suplicando a Odisseu) remete à outra (Odisseu suplicando a Polifemo que o receba bem: Od. IX, 259-271), destaca-se a mudança de papel de Odisseu, de vítima para algoz em potencial.

No episódio do ciclope, portanto, o tema da fama está gravado no próprio nome do gigante, nome esse que só é mencionado, no canto inteiro, três vezes. O tema evocado pelo nome, porém, o precede. Quando Odisseu procura conquistar o respeito do ciclope, ele tenta se impor através de um lastro simbólico, as conquistas dos gregos em Troia; isso aponta para o contexto épico da narrativa de histórias após um banquete, seja através de um aedo, seja na boca do anfitrião ou do hóspede:

Nós, vê, de Troia, após vagar longe do curso - aqueus -, devido a todos os ventos por grande abismo de mar, ansiando ir para casa, por outra rota, outros percursos, viemos; assim, talvez, Zeus quis armar um plano. Tropa de Agamêmnon, filho de Atreu, proclamamos ser, desse cuja fama, agora, sob o páramo é a maior: grande cidade devastou e tropas dilacerou, ${ }^{14}$ muitas. Nós, porém, chegando, esses teus joelhos alcançamos, ${ }^{15}$ esperando nos acolheres bem ou mesmo dares um regalo, o que é costume entre hóspedes.

Mas respeita os deuses, poderoso; somos teus suplicantes. Zeus é o vingador de suplicantes e hóspedes, o dos-hóspedes, que respeitáveis hóspedes acompanha.

(Od. IX, 259-271)

\footnotetext{
${ }^{14}$ Compare esse verso e o início do próximo, em enjambement, com os primeiros quatro versos da Odisseia, que introduzem a história que está por vir: "Do varão me narra, Musa, do muitas-vias, que muito/vagou após a sacra cidade de Troia devastar./ De muitos homens viu urbes e a mente conheceu,/ e muitas aflições sofreu ele no mar, em seu ânimo..."

${ }^{15}$ Essa expressão caracteriza esse discurso como uma súplica.
} 
Essa fala como que antecipa aquela por meio da qual o aedo Fêmio suplica por sua vida a Odisseu, acenando-lhe com histórias:

Pego teus joelhos, Odisseu; tem-me respeito e piedade.

Para ti, no futuro, tormento haverá se um cantor matares, eu que para deuses e homens canto.

O que sei vem de mim; deus, em meu juízo, enredos de todo o tipo plantou; convém junto a ti cantar como a um deus. Assim não almejes degolar-me.

Também Telêmaco isto poderia dizer, teu caro filho, que eu nem de bom grado nem com aspirações tua casa frequentava para cantar aos pretendentes após os banquetes; muito mais numerosos e fortes, guiavam-me sob coação.

(Od.XXII, 344-353)

Uma diferença suplementar entre os discursos dos dois suplicantes é que Odisseu, diante de Polifemo, está convidando o gigante a ouvir uma história que ele pode contar com maestria, pois foi uma testemunha dos acontecimentos. A história que não vamos ouvir da boca do narrador Odisseu, naquele momento, é a de Agamêmnon. O único herói que importa, naquele momento, é o que vai derrotar Polifemo. Poderia explorar esse viés metanarrativo, que, aliás, dá forma à Odisseia como um todo, mas já foram arrolados elementos suficientes para se explorar a relação entre Polyphêmos, "famigerado" e a expressão que fecha o conto, "o famoso assunto" (p. 13).

Ao contrário de Polifemo, que, ao ouvir o nome "Agamêmnon", não esboça nenhuma reação, o médico, ao ouvir a apresentação do jagunço "Damázio, dos Siqueiras..." - teve um "sobressalto. Damázio, quem dêle não ouvira? O feroz de estórias de léguas, com dezenas de carregadas mortes, homem perigosíssimo" (p. 10). Pouco ouvimos desse Damázio, assim como pouco ouvimos acerca do próprio médico; o que é famoso no final do conto, e permanece famoso enquanto a história continuar a ser lida, é a própria história, a história sobre um curioso sinônimo de "famoso". Mais que em qualquer outro conto do volume, a ação, portanto, a memória, a fama de "Famigerado" concentra-se em uma única palavra. O mesmo vale para história do cegamento de Polifemo tal como construída pela Odisseia: paradoxalmente, tal história é melhor condensada pelo nome do ciclope que pelo astucioso/famoso "Ninguém"; ou não?

A essa altura já deve estar claro que, embora o médico esteja para Odisseu assim como o jagunço está para Polifemo, há certos elementos que produzem uma reversão desse paralelismo. Assim, tanto na Odisseia 
quando em "Famigerado", decorre da ignorância o movimento de uma personagem em direção a um espaço que não lhe é familiar, ${ }^{16}$ algo comum a Odisseu e ao jagunço e que nos indica que Polifemo, ao contrário do médico diante do jagunço, só não se sente ameaçado pelos invasores de sua caverna por conta da brutal diferença de força entre ele e os humanos. Não é por coincidência que o primeiro olhar do ciclope sobre os homens que encontra reproduz a imagem da primeira aventura contada por Odisseu, uma pilhagem:

Estranhos, quem sois? Donde navegastes por fluentes vias?

Acaso devido a um negócio ou à toa vagais

tal como piratas sobre o mar? Esses vagam

arriscando suas vidas, dano a gentes alheias levando.

(Od. IX, 252-255)

Vamos, que também meu retorno muita-agrura eu narre, o que Zeus me enviou quando eu de Troia voltava.

Levando-me de Ílion, o vento achegou-me dos cícones, de Ismaros; lá eu saqueei a cidade e os matei.

Da cidade tendo tomado as esposas e muitas posses, dividimos para eu ninguém deixar sem sua parte.

(Od. IX, 37-42)

Assim como Polifemo, o médico interpreta os motivos da visita do estranho, mesmo após esse revelar sua identidade e dizer a que veio, do ponto de vista mais negativo possível. ${ }^{17}$ Ambos estão, ao mesmo tempo, certos e errados em seus diagnósticos: o médico, por conta de sua experiência e pelo modo como se desenrola a história; Polifemo, pelo que nos conta o próprio narrador, Odisseu, acerca de seus companheiros, que, antes da chegada do ciclope, haviam proposto um saque seguido de uma fuga:

\footnotetext{
${ }^{16}$ A curiosidade de Odisseu é salientada não só diretamente, mas também por contraste, já que não há falta de comida, uma das razões que se esperaria nesse tipo de situação.

${ }^{17}$ Logo no $2{ }^{\circ}$ parágrafo: Tomei-me nos nervos. O cavaleiro êsse-o oh-homem-oh-com cara de nenhum amigo. Sei o que é influência de fisionomia. Saíra e viera, aquêle homem, para morrerem guerra (cf. Rosa, op. cit., 1967, p. 9). E após a 1a formulação do problema da palavra ouvida: Ejá aí outro susto vertiginoso suspendia-me: alguém podia ter feito intriga, invencionice de atribuir-me a palavra de ofensa àquele homem (cf. Rosa, op. cit., 1967, p. 11).
} 


\begin{abstract}
Após chegar no antro, contemplamos tudo, cestos abarrotados de queijo, cercados repletos de ovelhas e cabritos: separados por categorias, encerrados, à parte os mais velhos, à parte medianos, à parte filhotes. Todas as vasilhas transbordavam de soro, e baldes e tigelas, fabricadas, com as quais ordenhava. Lá os companheiros suplicaram-me para, primeiro, pegar algum queijo e voltar, e depois, celeremente, até a nau veloz cabritos e ovelhas dos cercados arrastar e navegar pela água salgada; mas não obedeci (e teria sido muito mais vantajoso) para poder vê-lo, esperando que me desse regalos.
\end{abstract}

(Od. IX, 218-229)

Antes, Odisseu havia mencionado outra razão para navegar da Ilha das Cabras para a ilha vizinha, não explicitamente enunciando a possibilidade de um ganho material como motivação primeira:

Os outros, vós aqui ficai, meus leais companheiros;

mas eu, com minha nau e meus companheiros, vou verificar esses homens, de que tipo eles são, se desmedidos, selvagens e não civilizados, ou hospitaleiros, com mente que teme o deus.

(Od. IX, 172-176)

A hospitalidade, ou seja, a possibilidade de estabelecer algum tipo de contato lucrativo de forma civilizada com os moradores de uma região desconhecida, vale dizer, seguindo protocolos aristocráticos, é o que motiva Odisseu. Ele próprio, porém, ao decidir levar junto um odre de precioso vinho (Od.IX, 193-215), não segue esse código, segundo o qual só o visitante recebe uma dádiva do visitado, que, por sua vez, espera que no futuro ocorra a recíproca.

No canto IX, é clara a autoconfiança de Odisseu, que, mesmo cogitando que poderia deparar alguém selvagem, ${ }^{18}$ prefere arriscar, achando que o valor do objeto que ofereceria como dádiva (xeínia, v. 229) seria suficiente para garantir um comportamento civilizado (díkaios) da parte de quem porventura encontrasse. O que motiva Odisseu a levar o vinho, portanto, é o desejo muito heroico de aumentar sua riqueza. Estamos

\footnotetext{
${ }^{18}$ Cf. v. 214-215: "Que encontraria varão vestido com grande bravura,/ selvagem, não conhecendo bem tradições nem normas".
} 
longe da imagem de Odisseu, muitas vezes utilizada na recepção da personagem, como alguém motivado pela curiosidade.

Os códigos ligados à hospitalidade também perpassam todo o conto de JGR, embora aqui não tenham a função acentuadamente irônica, tingidos por um certo humor negro mesmo, que adquirem na passagem odisseica, quando são burlados um após o outro. ${ }^{19} \mathrm{O}$ médico convida o jagunço a entrar na sua casa (p. 9), mas Damázio "disse de não, conquanto os costumes", num primeiro momento ainda sobre o cavalo, mas então "desfranziu-se, porém, quase que sorriu. Daí, desceu do cavalo; maneiro, imprevisto. Se por se cumprir do maior valor de melhores modos; por esperteza?” (p. 10). O narrador nos informa, então, que, se o jagunço tivesse aceito um café, ele ter-se-ia acalmado, indicando, portanto, que dentro de certos limites, o comportamento do outro poderia ser previsto: "Assim, porém, banda de fora, sem a-graças de hóspede nem surdez de paredes, tinha para um se inquietar, sem medida e sem certeza" (p. 10). No final, após receber a resposta que buscava, aceita um copo d'água, "agradeceu, quis me apertar a mão. Outra vez, aceitaria de entrar em minha casa" (p. 12). Nas duas narrativas, portanto, a hospitalidade, que nunca acontece do seu modo regular, esperado, é um tema importante a estruturar a narração e, sobretudo, a jogar com as expectativas do leitor, ele próprio acostumado com certos protocolos presumidos em ambos os textos.

Que o jagunço recuse a hospitalidade plena do médico, esse também é um elemento que o aproxima da representação do ciclope na Odisseia. Desde o início do conto, fica claro que não é o médico que está no controle do tempo e do espaço do encontro. Paradoxalmente, isso acontece pela recusa mesma do jagunço de entrar na casa, o que, ao mesmo tempo que permite ao médico permanecer dentro da casa, cria uma espécie de espaço intermediário e não obriga o jagunço a se concentrar num espaço que lhe seria muito estranho.

Assim como a inteligência do jagunço vai sendo explicitada aos poucos - por exemplo, no terceiro parágrafo menciona-se o modo astuto como posiciona os cavalos dos outros três cavaleiros -, o mesmo se dá com sua monstruosidade e violência, de sorte que é com uma certa surpresa que, logo após a primeira fala do jagunço, ouvimos tal descrição

\footnotetext{
${ }^{19}$ Para citar apenas alguns, não há uma troca de nomes entre Odisseu e Polifemo; aquele só fica sabendo do nome deste através dos vizinhos que atendem aos gritos do cegado, e aquele revela seu nome durante o banquete, mas no qual foram devorados seus companheiros e apenas após embebedar seu anfitrião, que, como retribuição pelo presente recebido, decide devorar o hóspede por último.
} 
feita pelo narrador: "Carregara a celha. Causava outra inquietude, sua farrusca, catadura de canibal” (p. 10). O semblante de canibal é surpreendente, e a repetição da sílaba "ca" confere destaque ao substantivo no final da frase.

Esse me parece outro elemento forte a sustentar a Odisseia como intertexto do conto. $\mathrm{O}$ trecho acima abre o parágrafo no qual a violência possível do jagunço alcança sua representação mais acentuada: "Tudo de gente brava. Aquêle propunha sangue, em suas tenções. Pequeno, mas duro, grossudo, todo em tronco de árvore. Sua máxima violência podia ser para cada momento". Por um átimo, Damázio praticamente deixa de ser um humano para se tornar um elemento da natureza. Vale lembrar que o narrador, ao compor sua narração, já possui o conhecimento acerca da identidade de quem está diante dele. No conto "Os irmãos Dagobé", a população do vilarejo, acostumada com os desmandos do irmão mais velho, Damastor, julga de forma equivocada as ações dos outros três ao longo do conto, sempre esperando um desfecho violento. Em "Famigerado", o narrador cria, desde o início do conto, a mesma impressão, tanto mais palpável por ser ele participante ativo da ação. Nada nos garante, porém, que, caso a interpretação do termo "famigerado" fosse outra, o destino do médico seria nefasto.

Voltando a Polifemo, já na introdução do episódio seu caráter monstruoso é destacado: "De fato, era um assombro portentoso, e não parecia/ um varão come-pão, mas um pico matoso/ dos altos montes, que surge só, longe dos outros” (v. 190-192). Quando ele entra em cena, sua monstruosidade, porém, é marcada através de suas ações, em primeiro lugar, através da pedra descomunal que movimenta para fechar sua gruta após nela entrar (v. 240-243). Sua ação mais terrível, porém, é o modo como mata os companheiros de Odisseu, e é subordinada a ela a comparação a um leão da montanha:

Assim falei, e não me respondeu com impiedoso ânimo, mas, de súbito, sobre companheiros estendeu as mãos, e, tendo dois agarrado, como cachorrinhos ao chão arrojou-os: miolos escorriam no chão e molhavam o solo. Após cortá-los em pedaços, aprontou o jantar; comia-os como leão da montanha, e nada deixou, vísceras, carnes e ossos cheios de tutano.

(Od. IX, 287-293)

A cena de canibalismo em si já é um retrato suficientemente horrível, de sorte que é de menor importância se ele come os homens 
crus ou não. ${ }^{20}$ Os versos 291-293, de fato, não me parecem esclarecedores nesse sentido, mas é certo que eles dão sequência, através da sua minúcia, ao quadro de horror.

Duas criaturas monstruosas, portanto, duas máquinas de matar, ${ }^{21}$ ambas, porém, fazem uso da astúcia. Tanto Damázio quanto Polifemo percebem que vale a pena uma certa contenção de suas vontades imediatas, respectivamente, descobrir o sentido de "famigerado" e comer a carne de seus hóspedes; ambos averiguam seus interlocutores. Nem no conto nem no poema épico o narrador-personagem nos dá claras, explícitas razões para isso.

A primeira pergunta de Polifemo é acerca da identidade dos forasteiros: "Estranhos, quem sois? Donde navegastes por fluentes vias? Acaso devido a um negócio ou à toa vagais tal como piratas sobre o mar? Esses vagam arriscando suas vidas, dano a gentes alheias levando" (v. 252-255). A descrição anterior do ciclope não nos faz acreditar que ele esteja com medo dos humanos, de sorte que a pergunta parece ter antes a função de indicar aos feácios e a nós que os companheiros quiseram, ao contrário de Odisseu, se comportar como piratas. Ao mesmo tempo, porém, podemos ler a variação de uma pergunta tradicional sobre a identidade como ironia por parte do ciclope, que já adiantaria aquilo que, ato contínuo, transformará em ação: quem trará dano é ele próprio. ${ }^{22}$ Dessa forma, o ciclope revela um domínio da linguagem que ultrapassa o meramente instrumental, embora os versos subsequentes solapem essa interpretação, pois Odisseu apresenta seu adversário como um bruto monstruoso, alguém que é pura voz amedrontadora: "Assim falou, e rachou-se nosso coração,/ atemorizados com a voz pesada e o portento em si" (v. 256-257).

${ }^{20}$ Cf. O'Sullivan, J. N. Observations on the "Kyklôpeia". Symbolae Osloenses. Oslo, vol. LXII, p. 5-24, 1987, aqui, p. 18: o autor defende, contra a communis opinio, que a carne é cozida; os defensores da omofagia costumam utilizar a comparação com o leão para sustentar sua posição.

${ }^{21}$ Diz o narrador acerca de Damázio: Seria de ver-se: estava em armas - $e$ de armas alimpadas. Dava para se sentir o pêso da de fogo, no cinturão, que usado baixo, para ela estar-se já ao nível justo, ademão, tanto que êle se persisitia de braço direito pendido, pronto meneável (cf. Rosa, op. cit., 1967, p. 10).

${ }^{22}$ Para uma desconstrução de uma polaridade rígida civilizado x não-civilizado na caracterização de Polifemo (diante dos aparentemente ultracivilizados feácios), cf. Pucci, P. The song of the Sirens. Essays on Homer. Lanham: Rowman \& Littlefield, 1998, p. 113-130. 
O temor físico produzido pelo ciclope está em consonância com o que acontece na sequência: à menção do exército vitorioso de Odisseu e sua súplica na qual utiliza Zeus como deus protetor dos suplicantes (v. 259-271), Polifemo responde que, para os ciclopes, leis divinas e deuses não importam. A imagem primeira dos ciclopes, feita pelo narrador Odisseu, revela-se, porém, em uma certa desconformidade com aquilo que a própria personagem diz de si mesma:

E à terra dos ciclopes, soberbos, desregrados, chegamos, eles que, confiantes nos deuses imortais, árvores não plantam com as mãos nem aram, mas, sem semear-se e arar-se, isso tudo germina, trigo, cevada e videiras, que produzem vinho de grandes uvas que a chuva de Zeus lhes fomenta.

(Od. IX, 106-111)

Isso coloca em dúvida a autoridade desse narrador e alerta o receptor para fissuras talvez não muito aparentes na representação:

És tolo, estrangeiro, ou vieste de longe, tu que me pedes aos deuses temer ou evitar.

Os ciclopes não se preocupam com Zeus porta-égide nem com deuses ditosos, pois somos bem mais poderosos; nem eu, para evitar a braveza de Zeus, pouparia a ti ou teus companheiros se o ânimo não me pedisse.

(Od. IX, 273-278)

Os problemas do trecho que introduz a aventura junto aos ciclopes (v. 106-114) são conhecidos e diversas tentativas para solucioná-los já foram feitas, ${ }^{23}$ mas é inegável haver uma tensão entre a apresentação inicial, que evoca uma idade do ouro na qual, tradicionalmente, deuses e homens vivem em comunhão - a ausência da necessidade de trabalho é suficiente para marcar essa situação,$-{ }^{24}$ e o desprezo pelos deuses (olímpicos) contido na fala de Polifemo.

Outra pergunta que revela uma certa esperteza por parte de Polifemo é um apêndice à primeira vista anódino por meio do qual ele indaga o ponto em que a nau dos estranhos foi ancorada:

${ }^{23}$ Cf. Scodel, R. Odysseus' ethnographic digressions. In: Raber, R. J. (Org.). Approaches to Homer, ancient and modern. Swansea: Classical Press of Wales, 2005, p. 147-166.

${ }^{24}$ Cf. a história de Prometeu e Pandora e a imediatamente subsequente representação da espécie de ouro em Trabalhos e dias 42-126. 


\begin{abstract}
"Mas dize-me onde aportaste a nau engenhosa, algures no extremo ou perto, para que eu saiba”. Assim falou, testando-me, e eu, mui arguto, percebi; respondendo, disse-lhe com palavras ardilosas: "Minha nau despedaçou Poseidon treme-solo; contra rochedo lançou-a nos limites de vossa terra, rumo ao cabo levando-a; vento trouxe-a do mar. Mas eu, com esses aí, escapei do abrupto fim”.
\end{abstract}

(Od. IX, 279-286)

O narrador percebe o truque do monstro, nos informa que se trata de argúcia (peirázon, v. 281) ${ }^{25}$ e reage à altura. Esse trecho sugere, portanto, que, em certas passagens, pode estar implícita uma tendência de se subestimar a esperteza do ciclope por parte de Odisseu, o que eventualmente deixa de ser notado pelo leitor do poema, para quem é a estupidez de Polifemo a responsável por sua derrota. O modo como essa ocorre, porém, é estúpido para nós, que, ao lado de Odisseu, olhamos para o grandalhão derrotado com desprezo após a façanha ter sido realizada.

O que se verifica na representação ambígua de Polifemo repete-se, até certo ponto, na caracterização de Damázio. Via de regra, a crítica o apresenta como uma personagem focada exclusivamente na sua força e violência. José Miguel Wisnik fala da personagem como "um homem cuja linguagem é a da faca e a da bala"; ${ }^{26}$ para Yudith Rosenbaum, "fora de seu código da jagunçagem, é um ser perdido e vulnerável". ${ }^{27}$ Vulnerável, talvez, mas perdido e limitado à força bruta é, no mínimo, uma caracterização parcial. A leitura dos pequenos gestos do adversário é acentuada pelo narrador no que diz respeito a si mesmo, por exemplo: "A conversa era para teias de aranha. Eu tinha de entender-lhe as mínimas entonações" (p. 11). O mesmo, porém, vale para o jagunço, pois sabe que se encontra em território estranho, mas quer algo que é intrínseco a esse mundo diferente, ou seja, algo que precisa obter sem fazer uso da sua arma mais óbvia, a violência.

O cavaleiro é, bem no início do texto, apresentado como solerte, um adjetivo que, em GSV, diz respeito à inteligência e à astúcia na sua

\footnotetext{
${ }^{25}$ Algumas passagens em que "testar" e termos cognatos estão ligados à astúcia silenciosa na Odisseia:XVIII, 333-338; XIV, 459-461; XV, 302-324; XXIII, 173-182.

${ }^{26}$ Cf. Wisnik, op. cit., p. 181.

${ }^{27}$ Cf. Rosenbaum, op. cit., p. 9.
} 
forma mais elegante e certeira, sempre com uma conotação positiva: ${ }^{28}$ "O cavaleiro solerte tinha o ar de regê-los: a meio-gesto, desprezivo, intimara-os de pegarem o lugar onde agora se encostavam" (p. 9). Isso é tanto mais significativo nessa passagem porque tal solércia refere-se ao modo como o jagunço comanda os três pobres-diabos que com ele estão, ou seja, se pensarmos na Odisseia, o paralelo é eficaz e divertido: como Odisseu, o jagunço não deixa os homens voltarem; como Polifemo, cria uma barreira física. A inteligência, claro, não deixa de estar ligada à brabeza de Damázio. ${ }^{29}$ Entretanto, o doutor, naquele momento, é puro medo: "Com um pingo no i, êle me dissolvia. O mêdo é a extrema ignorância em momento muito agudo. $\mathrm{O}$ mêdo $\mathrm{O}$. O mêdo me miava" (p. 9). ${ }^{30}$ Para o doutor, Damázio parece, no início do conto, ser puro pensamento: "Via-se que passara a descansar na sela - decerto relaxava o corpo para dar-se mais à ingente tarefa de pensar" (p. 10). Repare-se no adjetivo "ingente", que significa "descomunal, desmedido": por um lado, inclusive pelo seu registro erudito, pode indicar um certo desprezo do narrador-personagem, que escreve após o acontecido, portanto, ainda que de forma discreta, é capaz de julgar seu adversário após este ter sido subjugado. Tendo em vista o paralelo com a Odisseia, "ingente" parece se referir a um cérebro pequeno em um corpo enorme.

Não se trata de uma interpretação obrigatória, porém. $\mathrm{O}$ adjetivo talvez nos indique que, embora armado e, portanto, numa posição de vantagem, o jagunço, nesse momento, está focado em outra tarefa, e para essa usa outras armas, e da melhor forma que puder. De fato, mais do que uma dificuldade momentânea, o médico percebe um certo

${ }^{28}$ Por exemplo, em Rosa, J. G., Grande sertão: veredas. 20a edição. Rio de Janeiro: Nova Fronteira, 1986, p. 77: Cara de Marcelino Pampa ficou enorme. Do que constei dos outros, concordantes, estabeleci que eu tinha acertado solerte - dei na barra!; e na p. 215: Aprecio uns assim feito o senhor - homem sagaz solerte. Para o uso do adjetivo em PE, cf. conto especular de "Famigerado", "Tarantão meu patrão": Lá se ia, se fugia, o meu esmarte Patrão, solerte se levantando da cama, fazendo das dêle, velozmente, o artimanhoso (p. 158). Na arquitetura de Primeiras estórias, o último e o primeiro conto, o $23^{\circ}$ e o $2^{\circ}$ e assim por diante formam pares especulares até o conto central, "O espelho". Essa "sequência" (o termo que da título ao último conto antes de "O espelho") também é "grega", a anelar (Ringkomposition), comum - mas não apenas - na literatura oral.

${ }^{29}$ Cf. Rosa, op. cit., 1967, p. 9: Tudo enxergara, tomando ganho da topografia. Os três seriam seus prisioneiros, não seus sequazes. Aquêle homem, para proceder da forma, só podia ser um brabo sertanejo, jagunço até na escuma do bofe.

${ }^{30}$ Para Wisnik, op. cit., p. 181, um “0” (zero); no imaginário metafísico roseano, a evocação é antes ao oco que ao nada ou à ausência da letra. 
comportamento astuto como marca desse jagunço: "Sua voz se espaçava, querendo-se calma; a fala de gente de mais longe, talvez são-franciscano. Sei dêsse tipo de valentão que nada alardeia, sem farroma. Mas avessado, estranhão, perverso brusco, podendo desfechar com algo, de repente, por um és-não-és" (p. 10). Esse é o tipo de heroísmo que Odisseu incorpora, tanto na Ilíada quanto, sobretudo, na Odisseia. ${ }^{32}$ O erro de Polifemo é ignorar que aquele fracote poderia ter uma habilidade heroica capaz de derrotá-lo. Quanto ao leitor de "Famigerado" que percebe esse paralelo, é mais fácil, nesse momento da narrativa, simpatizar com o jagunço e admirá-lo. Não se trata, por certo, de um Damastor. Até o próprio narrador consegue sair de seu medo, pois logo na sequência da frase há pouco citada, nos conta: "Muito de macio, mentalmente, comecei a me organizar" (p. 10). O jagunço não se tornou mais fraco; ele se tornou menos diferente do médico.

Damázio também domina a gestualidade. ${ }^{33}$ Logo após anunciar que veio pedir uma opinião do médico, produz a impressão de canibal citada acima. Só que ele franze a celha para imediatamente desfranzi-la: "Quase que sorriu” (p. 10); na sequência, desce do cavalo. ${ }^{34}$ O narrador fica sem saber se o que o jagunço faz é por bons modos ou esperteza, sendo que esta última, uma interpretação que concede máxima inteligência ao adversário - algo que é raro a crítica fazer com Damázio ou Polifemo -, parece mais condizente com a sequência da narrativa, na qual o narrador acentua a dificuldade de perceber o que o jagunço quer: "O que frouxo falava: de outras, diversas pessoas e coisas, da Serra, do São Ão, travados assuntos, insequentes, como dificultação. A conversa

\footnotetext{
31 "Farroma", um adjetivo regional, de acordo com o Houaiss, parece estar em contraponto com o erudito "ingente".

${ }^{32}$ Compare-se com Odisseu entre os jovens feácios durante o festejo por meio de provas atléticas no canto VIII. Que Odisseu, nesse momento da narrativa, está longe de um herói como aqueles da Ilíada que, com frequência, após derrotarem um adversário, produzem um, amiúde bastante elaborado, discurso de triunfo, isso fica claro no fim do canto VIII, quando, após Demódoco cantar o canto solicitado pelo próprio Odisseu - seu triunfo em Troia como líder da tocaia do cavalo de pau -, o herói sucumbe às lágrimas e é comparado a uma cativa de guerra pelo narrador.

${ }^{33}$ Para um domínio do corpo como contraponto à performance de um discurso, cf. a comparação entre as performances discursivas de Odisseu e Menelau no canto III da Ilíada.

${ }^{34}$ A passagem foi citada na íntegra supra.
} 
era para teias de aranha. Eu tinha de entender-lhe as mínimas entonações, seguir seus propósitos e silêncios. Assim no fechar-se com o jôgo, sonso, no me iludir, ele enigmava" (p. 11). Não poderia ser dito de forma mais contundente que o longo monólogo de Damázio ("Redigiu seu monologar”, p. 11), que não ouvimos, é construído com cuidado. ${ }^{35}$

Assim, se, quanto à pragmática, Damázio domina muito bem os códigos de comunicação, tão bem que o letrado doutor precisa de toda a concentração para não se deixar iludir pelo jagunço, então o que distingue as duas personagens? A resposta é simples, explicitada no próprio texto: o conhecimento daquilo que o dicionário informa, na definição de Damázio, "o livro que aprende as palavras" (p. 11).

Do ponto de vista do médico, ele pode, ao modo de Odisseu, enganar o jagunço duplamente sem deixar o outro perceber que está sendo enganado: ao informar o sentido de "famigerado" utiliza o sentido primeiro tal como informado por dicionário e ao jurar que esse é o sentido o faz através de uma formulação que manipula o sentido segundo, aquele usado pelo moço do governo para provocar ou denegrir o jagunço. Do ponto de vista do jagunço, nada mudará, pelo menos em curto prazo, na Serra do São Ão. Do nosso ponto de vista, que sabemos o que aconteceu e acompanhamos o diálogo por meio do olhar do médico, resta decidir o que é mais admirável: se, nas palavras laudatórias do jagunço dirigidas ao médico, "as grandezas machas de uma pessoa instruída" (p. 13) ou a grandeza, provocadora de admiração e terror, do jagunço.

O conhecimento linguístico de Damázio em sentido amplo não pode ser menosprezado. Do ponto de vista pragmático, ele está certo na sua desconfiança: o contexto extralinguístico que "o môço do Govêrno" e ele compartilham indica-lhe que o termo tenha sido usado como "nome de ofensa" (p. 12). Entretanto, como uma espécie de bom leitor de JGR, ele desconfia de seus hábitos linguísticos e vai atrás do verdadeiro sentido do termo, ou seja, de uma certeza. Mais que isso: ele explora a palavra que ouviu, atrás dos significantes que a parecem constituir: "masmisgerado... faz-me-gerado... falmisgeraldo... familhas-gerado..." (p. 11).

\footnotetext{
${ }^{35}$ Para figurar esse tipo de astúcia, compare-se esta atitutde com aquela do narrador de "O espelho" (PA, 74): Operava com tôda a sorte de astúcias: o rapidíssimo relance, os golpes de esguelha, a longa obliquidade apurada, as contra-surprêsas, a finta de pálpebras, a tocaia com a luz de-repente acêsa, os ângulos variados incessantemente. Sobretudo, uma inembotável paciência. Paciência é uma excelência central de Odisseu, mas como reverso do sofrimento; cf. Pucci, P. Odysseus polutropos. Intertextual readings in the "Odyssey" and the "Iliad". Ithaca: Cornell University Press, 1995, p. 56-75.
} 
Com isso, faz uso de um recurso poético-linguístico muito explorado por JGR. Neste conto, é o caso, por exemplo, do termo "insequente": "O que frouxo falava: de outras, diversas pessoas e coisas, da Serra, do São Ão, travados assuntos, insequentes, como dificultação" (p. 11). O neologismo, ao mesmo tempo, se refere a temas apresentados fora de sequência e a temas inconsequentes, palavra essa que soa em conjunto com o adjetivo criado, como no caso das multiformas orais de "famigerado". O jagunço, porém, ao contrário do romancista e de seus leitores mais cultos ou ávidos por um dicionário, é obrigado a se subordinar à informação linguística, quiçá pragmaticamente equivocada, fornecida por terceiros. O mesmo vale para aqueles leitores de Rosa que, se não conhecerem o sentido original do termo e não forem ao dicionário, talvez suponham que o médico tenha apenas mentido. Mesmo para esses, porém, o conto fornece uma série de pistas que indicam que não se trata só disso.

Todavia, como a crítica sempre de novo destacou, o conto não termina com a exibição de virtuosismo linguístico por parte do narrador, mas com a explicitação de uma sua carência, a fazer par com a carência linguística do jagunço. Diz ele, quando o jagunço lhe pede que garanta que aquilo que está dizendo é a verdade: "Olhe: eu, como o sr. me vê, com vantagens, hum, o que eu queria uma hora destas era ser famigerado bem famigerado, o mais que pudesse!...” Ora, agora sim, todo leitor do conto entenderá que se trata do sentido do termo com o qual está acostumado. Nessa revelação do narrador, que ele faz questão de enunciar para nós ter sido dita com sinceridade ("Do que o diabo, então eu sincero disse”, p. 12), surpreende o menospreçamento pelas armas linguísticas que usou. Estamos diante do oposto da bazófia de Odisseu no final da sua história; além disso, não há, pelo menos até esse instante do conto, nenhum sinal inequívoco de desprezo do médico pelo jagunço.

Em "Famigerado", o médico mente dizendo que o jagunço foi chamado de "célebre"; ao mesmo tempo, deixa claro que não é um macho de ação ao modo do outro, o que gostaria, porém, de ser. $\mathrm{Na}$ Odisseia, ao contrário, Odisseu não se segura e precisa gritar para o Ciclope que é um herói, de novo contra o conselho mais sábio dos companheiros:

Mas após percorrer, no mar, distância duas vezes maior, então quis chamar o Ciclope; em volta, companheiros, com fala amável tentavam conter-me de todos os lados: "Implacável! Por que queres provocar o varão selvagem? Agora mesmo projetou projétil ao mar e levou a nau 
de novo à costa, e já pensávamos lá perecer.

Se ele ouvir o som ou a fala de alguém,

despedaçará nossas cabeças e as tábuas da nau

ao projetar rochedo pontudo: tão longe arremessa”.

Assim falaram, mas sem convencer meu ânimo enérgico,

e, respondendo, disse-lhe com ânimo rancoroso:

"Ciclope, se a ti algum homem mortal

interpelar sobre o ultrajante cegamento do olho,

afirma que Odisseu arrasa-urbe te cegou,

o filho de Laerte, que tem sua casa em Ítaca”.

(Od. IX, 491-505)

Polifemo, porém, insiste em que a imagem sustentada pela alcunha "Ninguém" corresponde à realidade; o que o enganou foi (a interpretação que fez de) uma profecia antiga:

Incrível, de fato alcançou-me velho dito divino.

Havia aqui um adivinho, varão belo e grande,

Telemo, filho de Eurimo, que, superior na adivinhação,

envelheceu adivinhando para os Ciclopes;

afirmou-me que tudo isso se completaria no futuro,

que, nas mãos de Odisseu, eu perderia a visão.

Mas sempre um herói grande e belo esperei

que aqui chegasse, investido de grande bravura;

agora a mim um pequeno, um nada, um fracote

o olho cegou, após me subjugar com vinho.

(Od. IX, 507-516)

O último enganado, porém, é Odisseu, que, ao se crer a salvo, anuncia seu nome, com o que, sem o saber, não dá sustentação para sua identidade pregressa, a iliádica, a base de sua fama até aquele momento, mas dá início a sua história futura, pois, com a prece de Polifemo ao pai, começará a errância que tornará o herói, do ponto de vista do poema, ainda mais famoso. De fato, ao se referir ao seu nome como klutós ("famoso, glorioso", v. 364), ele se refere, ao mesmo tempo, ao nome que anunciara de forma tonitruante aos feácios, "Odisseu” (v. 9-10), mas também a "Ninguém" (v. 364-367). Sua fama, na economia da Odisseia, é dupla e indissociável de dois nomes: Odisseu e Ninguém, o cegamento do ciclope e o cavalo de Troia. Odisseu é conhecido entre todos os homens por todos os truques; do ponto de vista da sua performance diante dos feácios, sua fama tem base no passado, presente e futuro. 
Fama: não tenho certeza acerca do valor das últimas expressões do conto: "Esporou, foi-se, o alazão, não pensava no que o trouxera, tese para alto rir, e mais, o famoso assunto" (p. 13). No meio da frase, a focalização passa do jagunço para o médico, ou então de um narrador que às vezes parece onisciente (como sabe o que pensa o jagunço?) para um narrador que é personagem central da ação. Qual é a tese? De quem é a risada? Com as últimas palavras, o narrador anuncia a fama do conto (do livro?) no futuro? ? $^{36}$ Certo é que os eventos de "Famigerado" e de "Tarantão, meu patrão", as estórias que se espelham, ${ }^{37}$ quebram a polaridade entre o insignificante ("Não houve demo. Não houve morte", p. 166) e o grandioso ("aquilo tinha para grandêzas", p. 164) produzindo algo que merece ser rememorado. Essa não é a chave do episódio de Polifemo, no qual, para a astúcia se manifestar, gerando a história, precisase do cegamento do ciclope. ${ }^{38}$ É curioso que o cego anteriormente mencionado no poema tenha sido o bardo Demódoco e o próximo seja o adivinho Tirésias.

\section{Referências}

HOMERI Odyssea. Recognovit Helmut van Thiel. Hildesheim: Olms, 1991.

LORENZ, G. Diálogo com Guimarães Rosa. In: COUTINHO, E. F. (Org.) Guimarães Rosa. Rio de Janeiro: Civilização Brasileira, 1983, p. 61-97.

MARTINS COSTA, A. L. Rosa ledor de Homero. Revista da USP. São Paulo, n. 36, p. 46-73, 1997/1998.

O'SULLIVAN, J. N. Observations on the "Kyklôpeia". Symbolae Osloenses. Oslo, vol. LXII, p. 5-24, 1987.

PACHECO, A. P. Astúcia de classe: "Famigerado", de Guimarães Rosa, e o lugar do escritor. Terceira margem. Rio de Janeiro, vol.XXI, p. 131-139, 2009.

\footnotetext{
${ }^{36}$ Para uma análise da formulação "tese para alto rir", cf. Pacheco, op. cit., p. 136-37.

${ }^{37}$ Outro exemplo para sustentar esse espelhamento: compare, com as multiformas de "famigerado" mencionadas supra, as de "tarantão": "tapatrão, tapatrão... tarantão... tarantão... (...) 'João é João, meu Patrão...' Aí: e-patrapão, tampantrão, tarantão..." (p. 165).

${ }^{38}$ Odisseia IX, 410: "Se então ninguém (mê tís) a ti, que estás sozinho, violenta"; por homofonia, o ouvinte do poema também ouve "se então a astúcia (mêtis) a ti, que estás sozinho, violenta”. Odisseu, a astúcia corporificada, também necessita da violência, como demonstrado pelo modo como se vinga dos pretendentes de Penélope no canto XXII.
} 
PUCCI, P. Odysseus polutropos. Intertextual readings in the "Odyssey" and the "Iliad". Ithaca: Cornell University Press, 1995.

. The song of the Sirens. Essays on Homer. Lanham: Rowman \& Littlefield, 1998.

ROSA, J. G. Primeiras estórias. $3^{\text {a }}$ edição. Rio de Janeiro: José Olympio,1967.

. Grande sertão: veredas. 20ª edição. Rio de Janeiro: Nova Fronteira,1986.

ROSENBAUM, Y. A palavra como enigma. Aletria. Belo Horizonte, vol. VI, n. 13, p. 84-93, p. 2006.

ROSENFIELD, K. Desenveredando Rosa. A obra de J. G. Rosa e outros ensaios. Rio de Janeiro: Topbooks, 2006.

SCODEL, R. Odysseus' ethnographic digressions. In: RABEL, Robert J. (Org.) Approaches to Homer, ancient and modern. Swansea: Classical Press of Wales, 2005, p. 147-166.

WERNER, C. Reputação e presságio na assembleia homérica: "poluphemos” em “Odisseia” 2, 150. PhaoS. Campinas, vol. IX, p. 29-52, 2009.

WISNIK, J. M. O famigerado. Scripta. Belo Horizonte, vol. V, n.10, p. 177-189, 2002. 